\title{
Physical Activity and Meditation to Reduce Primary Dysmenorrhea in Adolescent
}

\author{
Komang Agus Jerry Widyanata \\ Nursing Academy of Kesdam IX/Udayana, Bali, Indonesia \\ jerry_akperkesdam@yahoo.com \\ Putu Intan Daryaswanti \\ Nursing Academy of Kesdam IX/Udayana, Bali, Indonesia
}

\author{
I Gede Yudiana Putra \\ Nursing Academy of Kesdam IX/Udayana, Bali, Indonesia
}

\begin{abstract}
Primary dysmenorrhea is menstrual pain occurring in the absence of pelvic pathology. It was caused by the production of neurotransmitter: prostaglandins. Psychological factors or stress can also cause dysmenorrhea. Physical activity and meditation are non-pharmacological treatments for this problem because of the effectiveness to reduce chronic menstrual pain. A total 40 female adolescents aged 16 - 18 years, who have primary dysmenorrhea at Senior High School of Health Bali Khresna Medika was divided into two groups randomly. Each groups contains 20 participants for physical activity treatment group and 20 for meditation treatment group. Menstrual pain scale measurements conducted in the two groups using the Visual Analogue Scale (VAS) before and after treatment. One group was delivered physical activity intervention and the other meditation twice a week for two months. The result of study showed that physical activity and meditation could reduce menstrual pain scale effectively $(\mathbf{p}<0.005)$. Based on the statistical analysis there was no significant difference between the effectiveness of physical activity and meditation $(\mathbf{p}>\mathbf{0 . 0 0 5})$ interventions. Physical activity and meditation can reduce menstrual pain level significantly.
\end{abstract}

Keywords-Dysmenorrheal, Physical activity, Meditation

\section{INTRODUCTION}

Dysmenorrhea is a severe, painful, cramping sensation in lower abdomen that often concurrently with other symptoms, such as sweating, headaches, nausea, vomiting, diarrhea, and tremulousness, all occurring just before or during menstruation period[1]. Almost half of reproductive women $(55 \%)$ suffered from dysmenorrhea in Indonesia. There are no exact risk factors to cause dysmenorrhea. It is associated with hormonal changes significantly in the menstrual period. Pain may occur during menses period or precede menses by 1 to 3 days[2].

Dysmenorrhea is divided into two categories, there are primary and secondary dysmenorrhea[3]. Primary dysmenorrhea is defined as recurrent, cramps pain occurring during menstruation with the absence of identifiable pelvic pathology. Secondary dysmenorrhea is menstrual pain associated with underlying pelvic pathology. Primary dysmenorrhea is caused by myometrial activity resulting in uterine ischemia causing pain[4][5]. This myometrial activity is modulated and augmented by prostaglandin synthesis[6].
Epidemiological studies in adolescent population (aged 1019 years) in the Lucknow district, Uttar Pradesh India found that the prevalence of dysmenorrhoea was $73.9 \%$ [7]. A cross-sectional study at Gorgia found that the prevalence of dysmenorrhea was $52.07 \%$ and due to pain, $69.78 \%$ reported frequent school absenteeism[8].

Dysmenorrhea can be more severe when affected by psychological and physical factors, such as stress, shock, blood vessel constriction, and anemic[9]. Dysmenorrheal primer with severe pain can limit normal daily activities that require pharmacological or non-pharmacological treatment. Pharmacological treatment with analgesics can reduce symptoms, such as aspirin and acetaminophen.

Non-pharmacological treatment has two categories; there are therapeutic modalities and complementary therapies. Nonpharmacological treatment is an effective method, especially in patients with chronic pain[10]. Treatment modalities include thermal therapy/warm compress therapies, progressive relaxation, and guided imagery. Many complementary therapies that can be chosen to reduce the menstrual pain, such as physical activity and meditation[11]. Physical activity can increase the endorphins production. It was a natural sedative that can increase the comforting sense. Meditation is a conscious effort to change how the mind works and how to be concentrated. Studies found that meditation has a positive effect on the psychological aspect. Some result studies found that, people who practice a regular meditation, have a low anxiety level, a good self-control and good self-actuality[12].

This study aimed to analyze the effectiveness of physical activity and meditation for reducing primary dysmenorrheal in adolescent girls.

\section{METHODS}

This Quasi-experimental study with nonrandomized pretest and post-test design[13] was conducted for four month from October 2016 to January 2017 at Health Senior High School Bali Khresna Medika. A total 40 adolescent girl who had primary dysmenorrhea were enrolled to be participants. They were divided into two groups randomly; there was 20 participants as a group with physical activity and 20 participants as a meditation group. Inclusion criteria were 
adolescent who have menstrual pain that lasted several hours before menstruation and lasts 48 hours to 72 hours. We excluded adolescence who aged over 21 years and have a pelvic disorder.

TABLE I. MENSTRUAL PAIN SCALE IN FEMALE ADOLESECENCE AT HEALTH SENIOR HIGH SCHOOL OF BALAI KHRESNA MEDIKA BEFORE AND AFTER TREATMENT

\begin{tabular}{|c|c|c|c|c|c|c|c|c|}
\hline \multirow{3}{*}{ Menstrual Pain Scale } & \multicolumn{4}{|c|}{ Physical Activity } & \multicolumn{4}{|c|}{ Meditation } \\
\hline & \multicolumn{2}{|c|}{$\begin{array}{c}\text { Pre- } \\
\text { treatme } \\
\text { nt }\end{array}$} & \multicolumn{2}{|c|}{$\begin{array}{c}\text { Post- } \\
\text { treatmen } \\
t\end{array}$} & \multicolumn{2}{|c|}{$\begin{array}{c}\text { Pre- } \\
\text { treatme } \\
\text { nt }\end{array}$} & \multicolumn{2}{|c|}{$\begin{array}{c}\text { Post- } \\
\text { treatmen } \\
t\end{array}$} \\
\hline & $\mathbf{n}$ & $\%$ & $\mathbf{n}$ & $\%$ & $\mathbf{n}$ & $\%$ & $\mathbf{n}$ & $\%$ \\
\hline No pain & $\mathbf{0}$ & $\mathbf{0}$ & $\mathbf{0}$ & $\mathbf{0}$ & $\mathbf{0}$ & $\mathbf{0}$ & $\mathbf{0}$ & $\mathbf{0}$ \\
\hline Mild menstrual pain & 4 & 20 & 20 & 100 & $\mathbf{0}$ & $\mathbf{0}$ & 10 & 50 \\
\hline $\begin{array}{l}\text { Moderate menstrual } \\
\text { pain }\end{array}$ & $\begin{array}{l}1 \\
6\end{array}$ & 80 & $\mathbf{0}$ & $\mathbf{0}$ & 11 & 55 & 9 & 45 \\
\hline Severe menstrual pain & $\mathbf{0}$ & $\mathbf{0}$ & $\mathbf{0}$ & $\mathbf{0}$ & 9 & 45 & 1 & 5 \\
\hline $\begin{array}{c}\text { Very Severe menstrual } \\
\text { pain }\end{array}$ & $\mathbf{0}$ & $\mathbf{0}$ & $\mathbf{0}$ & $\mathbf{0}$ & $\mathbf{0}$ & $\mathbf{0}$ & $\mathbf{0}$ & $\mathbf{0}$ \\
\hline Total & $\begin{array}{l}2 \\
\mathbf{0}\end{array}$ & $\begin{array}{c}10 \\
\mathbf{0}\end{array}$ & 20 & 100 & 20 & $\begin{array}{c}\mathbf{1 0} \\
\mathbf{0}\end{array}$ & 20 & 100 \\
\hline
\end{tabular}

TABLE II. WILCOXON SIGNED RANK TEST OF PHYSICAL ACTIVITY AND MEDITATION TO REDUCE PRIMARY DYSMENORRHEAL IN FEMALE ADOLESECENCE AT HEALTH SENIOR HIGH SCHOOL OF BALI KHRESNA MEDIKA

\begin{tabular}{cccc}
\hline Treatment Group & N & Mean rank & p value \\
\hline Physical Activity & & & \\
Pre-treatment & & 10.00 & 0.000 \\
Post-treatment & 20 & 0.00 & \\
Meditation & & & \\
Pre-treatment & & 8.43 & 0.001 \\
Post-treatment & 20 & 2.00 & \\
\hline
\end{tabular}

TABLE III. TABLE 3 INDEPENDENT T TEST OF PHYSICAL ACTIVITY AND MEDITATION TO REDUCE PRIMARY DYSMENORRHEAL IN FEMALE ADOLESECENCE AT HEALTH SENIOR HIGH SCHOOL OF BALI KHRESNA MEDIKA

\begin{tabular}{cccc}
\hline Treatment Group & N & $\begin{array}{c}\text { Mean } \\
\text { Rank }\end{array}$ & p-value \\
\hline Physical Activity & 20 & 2.20 & \\
Meditation & 20 & 2.20 & 1.000 \\
\hline
\end{tabular}

Menstrual pain assessment was done before and after treatment using Visual Analogue Scale (VAS). One group doing physical activity and one group doing the meditation twice a week for two months. After treatment, the menstrual pain scale was measured again. We used Wilcoxon Signed Rank Test to analyze the physical activity effectiveness and meditation effectiveness, and Independent $t$-Test to analyze the difference of effectiveness of both groups.

\section{RESULT}

This study included 40 female adolescence with difference menstrual pain scale. Analysis showed that before physical activity, a total of 16 participants $(80 \%)$ had moderate pain and 4 of participants $(20 \%)$ mild pain. Then after physical activity, all participants have decreased menstrual pain to mild pain category. In the meditation group, before treatment as a total 11 participants $(55 \%)$ have moderate menstrual pain, and 9 participant $(45 \%)$ have severe pain menstrual. then after treatment, a total of 10 participants decreased to mild menstrual pain, 9 participants experienced moderate pain, and 1 participant have severe menstrual pain.

Wilcoxon Signed Rank was conducted because Shapiro Wilk Test showed that the menstrual pain scale were not the normality data. Both of Physical activity and meditation can reduce dysmenorrhea significantly with $\mathrm{p}$ value $<0.005$ (Table 2).

The result of Independent t-test, showed that there was no effectiveness different between physical activity and meditation (Table 3). Both of them can reduce the primary dysmenorrhea in adolescences.

Table 3 Independent t-Test of Physical Activity and Meditation to reduce primary dysmenorrheal in female adolescences at Health senior high school of Bali Khresna Medika

\section{DISCUSSION}

The results of this study showed that $80 \%$ participants had moderate pain and $20 \%$ had mild pain. This result consistent with some results from previous studies, such as the study finding that $60-75 \%$ female adolescence had moderate pain and $25 \%$ had severe pain of menstrual[14]. Ref [15] showed that $46.7 \%$ of students experience dysmenorrhea in moderate pain.

The result of this study found that after treatment there are decreased pain scales. All participants who have moderate pain after treatment had mild pain when menstruation. Significant reduction of primary dysmenorrhea in adolescences before and after physical activity treatment. Same finding was showed as in [12], 50\% participants have pain scale reduced after regularly physical activity. We recommended mild physical exercise for adolescence with primary dysmenorrhea. Physical activity such as gymnastic can reduce dysmenorrhea. physical activity can reduce the pain because the body can produce Endorphin. This hormone has a function as a natural sedative make the body feel comfortable[16].

Before treatment, there was $55 \%$ participant have moderate pain, and $45 \%$ severe pain. From the data analysis, there was significant reduction in pain after meditation treatment. After meditation $50 \%$ participants have mild pain, $45 \%$ moderate pain, and $5 \%$ still on severe pain.

Further research revealed that when a brain was scanned after meditation training, the scan results showed that meditation can calm the brain regions that create pain. During meditation, the brain region seems totally calmed down in 
activity. In addition, the brain areas associated with sensing such as heat, cold, and pain. Meditation can give a real effect in the brain and can provide an alternative for people who want to reduce pain without drugs[17].

\section{CONCLUSION AND RECOMMENDATION}

Physical activity and meditation can reduce menstrual pain scale significantly. For both of them, there was no significant difference in effectiveness. As a recommendation, physical activity and meditation can be an option to reduce dysmenorrheal because the pharmacology treatment not effective for chronic menstrual pain.

\section{REFERENCES}

[1] G. Lentz, R. Lobo, and D. Gershenson, Comprehensive Gynecology. Philadelphia: Mosby Elsevier, 2012.

[2] H. E.-S. Mohamed, S. M. A.-A. Salem, and Z. Al-kotb, "Effect of using Femi-band acupressure on primary dysmenorrhea: Randomized controlled trial," J. Nurs. Educ. Pract., vol. 5, no. 12, pp. 49-56, 2015.

[3] I. Bobak, D. Lowdermilk, and M. Jensen, Buku Ajar Keperawatan Maternitas (Maternity Nursing), 4th ed. Jakarta: EGC, 1995.

[4] M. Akerland, "Pathophysiology of dysmenorrhea," Acta Obs. Gynecol, vol. 87, no. Suppl., pp. 27-32, 1979.

[5] G. Lefebre and O. Pinsonneault, "Primary Dysmenorrhea Consensus Guideline,” J. Obstet. Gynecol. Canada, 2005.

[6] A. Guyton and J. Hall, Buku Ajar Fisiologi Kedokteran, 9th ed. Jakarta: EGC, 1995.

[7] S. Sinha, J. . Srivastava, B. Sachan, and R. B. Singh, "A study of menstrual pattern and prevalence of dysmenorrhea during menstruation among school going adolescent girls in Lucknow district, Uttar Pradesh, India," Int J Community Med Public Heal., vol. 3, no. 5, pp. 1200-1203, 2016.

[8] T. Gagua, B. Tkeshelashvili, and D. Gagua, "Primary Dysmenorrhea: Prevalence in Adolescent Population of Tbilisi, Georgia and Risk Factors," J Turkish-German Gynecol Assoc, vol. 13, pp. 162-8, 2012.

[9] P. Hamilton, Dasar-Dasar Keperawatan Maternitas, 6th ed. Jakarta: EGC, 1989.

[10] K. Chang, R. Fillingim, R. Hurley, and S. Schmidt, "Chronic pain management: nonpharmacological therapies for chronic pain," FP Essent Pubmed, vol. 432, pp. 21-6, 2015.

[11] H. Ahcjar, "Terapi Modalitas (therapeutik modalities) Sebagai Alternative Tindakan mengatasi Nyeri Haid Remaja," 2009. [Online]. Available: http://komanghenny.blogspot.co.id/2009_06_01_archive.html.

[12] Asmara, "Efektivitas Senam Dismenore dalam mengurangi Disminore pada Remaja Putri di SMU Negeri 5 Semarang," 2009.

[13] S. Arikunto, Prosedur Penelitian, Suatu Pendekatan Praktek, Edisi Revi. Jakarta: PT Rineka Cipta, 2003.

[14] H. Hendrik, Problema haid: tinjauan syariat Islam dan medis. Solo: Penerbit Tiga Serangkai, 2006.

[15] Rofli and Marlinda, "Pengaruh Senam Disminore terhadap Penurunan Disminore pada Remaja Putri di Desa Sidoharjo Kecamatan Pati," J. Keperawatan Matern., vol. 1, no. 2, pp. 118 123, 2013.

[16] W. Harry, "Hubungan Kemampuan Aerobik dan Kondisi Psikologis pada Pelajar Laki-laki SMU Negeri 1 Prabumulih," Universitas Sriwijaya, 2005.

[17] P. Ayu, "Harian kompas: Meditasi Hilangkan Nyeri Tanpa Obat," 2016. [Online]. Available: http://health.kompas.com/read/2016/03/18/070900723/Meditasi.Hil angkan.Nyeri.Tanpa.Obat. 